\title{
Dialogism and classroom interaction in English language teaching: A review of Czech research ${ }^{1}$
}

\author{
František Tůma
}

Masaryk University, Faculty of Education, Institute for Research in School Education

Received 3 August 2014; final version received 24 October 2014; accepted 27 October 2014

\begin{abstract}
The aim of the present study is to review Czech research on classroom interaction in English language teaching. We understand classroom interaction as mutual influencing among a teacher and learners while teaching and learning. We view classroom interaction from the perspective of dialogism, which we use as a theoretical and epistemological framework assuming interaction as a unit of analysis. This review analyzes 9 empirical studies published as journal articles, books, book chapters or Ph.D. dissertations in the years 2006-2014. These studies were critically analyzed in the light of dialogism. Important findings include the fact that a number of studies dealt with teacher talk, mainly teacher questions and the use of the target language and the mother tongue. We compare the areas with the situation abroad as reflected in selected reviews of international research, and outline gaps in Czech research. As regards research methodology (and also theoretical background), a number of studies did not take context into consideration when analyzing classroom. Furthermore, it seems that the activity of individuals (teachers, learners) was the unit of analysis in the majority of studies rather than the interaction itself. These findings seem to suggest that dialogism was not employed in the empirical research to a greater extent.
\end{abstract}

Keywords: classroom interaction, dialogism, English language teaching, review of research

\section{Classroom interaction}

The shared activity and mutual influencing among teachers and learners constitute a fundamental part of the teaching and learning processes in the classroom. It is therefore vital that educational research describe and understand the nature of classroom interaction. In this article we introduce theoretical background for researching classroom interaction and then we

1 This study was supported by a grant CZ.1.07/2.3.00/30.0009 Employment of newly graduated doctors of science for scientific excellence.

DOI: 10.5817/PedOr2014-6-878 
critically $^{2}$ review empirical studies of classroom interaction in English language teaching conducted in the Czech Republic, focusing mainly on the extent to which dialogism was employed in the studies.

Due to the grounding of this review in dialogism we prefer the term classroom interaction to other terms such as classroom communication or classroom discourse, which seem to imply other theoretical and epistemological positions. We understand the term interaction in line with its etymology, i.e. comprising the prefix inter (between, among) and noun action borrowed from the Latin noun actio (performing, doing). This is compatible with the concept of dialogue, i.e. "any dyadic or polyadic interaction between individuals who are mutually co-present to each other and who interact through language (or some other symbolic means)" (Linell, 1998, p. 9). ${ }^{3}$ Classroom interaction therefore denotes the participants' mutual influencing and reacting realized primarily by means of spoken language. Although the concept of classroom can be extended to virtual classrooms (e.g. Nunan, 2005, pp. 237-238), in this study we consider the classroom to be a physical place in institutional settings where teachers and learners meet face-to-face in order for the learners to learn (see also Ellis, 2008, p. 776).

As far as the teaching of English as a foreign language (EFL) ${ }^{4}$ in the classroom is concerned, classroom interaction tends to be different from classroom interaction in other subjects taught in the teacher's and students' mother

2 This review is a critical analysis, i.e. it "identifies issues that were dominant in the previous research and the issues on which the following research should concentrate. The review critically assesses the shortcomings and dead ends of the previous research" (Mareš, 2013, p. 432). Relatedly, a "critical-polemical" presentation and interpretation is adopted here, which makes it possible to be selective. Thus the author "selects arguments in support of his favored approach and may ignore some positive aspects of other approaches" (Mareš, 2013, p. 433).

3 It should be pointed out that we are not referring to dialogue in the normative sense, i.e. the idea of "true" or "ideal" dialogue aiming at "a high degree of mutual empathy and/or open interaction characterized by symmetry and cooperation" (Linell, 2009, p. 5). In general, dialogism is concerned with an abstract understanding of dialogue, which may refer to "any kind of human sense-making, semiotic practice, action, interaction, thinking or communication, as long as these phenomena are 'dialogically'(or 'dialogistically') understood" (Linell, 2009, pp. 5-6). In this review, however, we concentrate mainly on (classroom) interaction between two or more persons, thus adopting the empirical definition of dialogue as cited above.

4 For the sake of consistency and with regard to the focus of this review (i.e. Czech research on classroom interaction) and cultural aspects of teaching English in the Czech Republic, we prefer to refer to English as a foreign language (EFL) rather than English as a second language (ESL). 
tongue because language in foreign language teaching has two functions: it serves as an interactional tool as well as a goal of teaching and learning. The target language therefore represents both the medium of instruction and at the same time the content (for a more detailed discussion, see Larsen-Freeman \& Freeman, 2008). It follows that classroom interaction in foreign language teaching, in our case in English language teaching, deserves special attention.

\section{Background for the review}

In this review we adopt dialogism as a theoretical and epistemological framework within which sociocultural theory casts light on the nature of mediated action, language and learning. Therefore the following overview of relevant concepts presents a background for the analysis of the studies.

\subsection{Interaction and dialogism ${ }^{5}$}

Although the terms dialogism and dialogue had been used by other authors (e.g. Bakhtin), it was Linell (1998) who clearly distinguished dialogism as an epistemological and theoretical framework from dialogue as the actual interaction. Linell $(1998,2009)$ introduces dialogism along with monologism, in whose opposition dialogism can be understood. Relatedly, Marková (1982) speaks of the Cartesian and Hegelian paradigms and Rommetveit (1988) of representational-computational and hermeneutic-dialogical approaches. Dialogism builds on a number of theories (Linell, 1998, pp. 40-54) including sociocultural theory, which we find relevant for this review as it casts light on the nature of language learning (see section 2.1). Since the area of our interest is that of classroom interaction, in the following paragraphs we characterize the presuppositions related primarily to the nature of interaction and language in dialogism, and briefly contrast them with the monologist presuppositions. A more detailed discussion can be found elsewhere (e.g. Linell, 1998, 2009; Marková, 1982).

Whereas in monologism the individual is viewed as an analytical unit, dialogism regards interactions, activities and situations as primary (Linell, 2009 , p. 15). In monologism, cognitive functioning is often viewed through the computational metaphor, which implies one-way understanding of communication. The speaker (sender) produces an utterance to be decoded by the listener (receiver), which presupposes the passive role of the listener

\footnotetext{
5 This section builds on our previous work published in Czech (Tůma, 2014, pp. 178-180).
} 
(Marková, 1982, pp. 60-79; Rommetveit, 1988). In response to this view, Bakthin holds that the idea of passive listener is fiction $(1986$, p. 68). Interaction in dialogism presupposes intersubjectivity, which implies an active role of participants who co-construct meaning together (Marková, 1982, pp. 140-183). It follows that each utterance presupposes a partner to whom it is addressed (Bakhtin, 1986, p. 72; Vološinov, 1973, p. 85). Relatedly, we can refer to the nature of mind. Whereas monologism views mind individualistically, in dialogism the mind is social (Linell, 1998, pp. 3-8; Luckmann, 1990; Marková, 1982, 2007).

It follows that in monologism, interaction is viewed as information transfer from the sender to the receiver. Thus interaction becomes "largely an epiphenomenon, reduceable to sequences of individual actions" (Linell, 1998, pp. 23-24). On the other hand, dialogism views interaction as a collective process in which the participants influence each other and in which any utterance "makes response to something and is calculated to be responded to in turn" (Vološinov, 1973, p. 72). Therefore unity is presupposed between interaction and context, cognition and communication, structure and process, individual and society, initiation and response etc., which are viewed as dichotomies in monologism (Linell, 1998, pp. 36-37; Marková, 1982).

From the above positions it follows that the context of interaction is viewed in different ways in the two frameworks. Whereas in monologism one can decontextualize utterances (Rommetveit, 1988), in dialogism context plays a crucial role (Luckmann, 1990, pp. 52-55; Vološinov, 1973, pp. 85-93). Context in dialogism can comprise the concrete situations, the surrounding utterances (co-texts) and background knowledge, including participants' knowledge of the referents and about each other (Linell, 2009, pp. 16-18). It should also be stressed that context in dialogism is viewed dynamically: on the one hand, the aspects of context are pre-structured, on the other hand, they are renewed and re-constructed during interaction (Linell, 1998, pp. 127-158). To summarize, in dialogism we understand interaction as a dynamic and situated process and we regard the participants as social beings.

\section{Mediated (inter)action, learning and language}

In dialogism it is generally presupposed that interaction is mediated by symbolic means. This can be specified within the framework of sociocultural theory (SCT), which also casts light on the nature of learning. Building on 
the works of Vygotsky and his co-workers, SCT explains human mental processes, taking into account their cultural, historical and institutional settings (Wertsch, 1991, p. 6).

In SCT, the unit of analysis is a mediated action, which also involves the participants and mediating tools, of which language is seen as central (Vygotsky, 1978, pp. 24-26, 52-57; Wertsch, 1991, pp. 8-13, 28-43). Mediated (inter)action is related to the functioning and development of higher mental functions, of which speech is of our interest. According to the general genetic law of cultural development, every function appears on two planes: first on the social (or interpsychological) plane, and then it is reconstructed onto the intrapsychological plane (Vygotsky, 1978, pp. 56-57, 1981). This reconstruction can be called internalization and is only possible if the function lies within the zone of proximal development of the individual (Vygotsky, 1978, pp. 55-57, 84-91, 1981; Wertsch, 1991, pp. 19-28) presupposing intersubjectivity between the learner and the more knowledgeable other. The concepts of mediation, zone of proximal development and internalization have been used in sociocultural second language acquisition (SLA) theory (e.g. Lantolf \& Thorne, 2006). This way language learning is conceptualized in relation to interaction.

As far as the nature of language is concerned, dialogism generally views language as a form of social action (for other views of language, see Cook, 2010), which can be referred to as a functional view of language (Schiffrin, 1994).

\subsection{Research on classroom interaction}

In general, the phenomenon of classroom interaction has been studied from a number of perspectives (not only dialogist ones), including quantitative observation methods, ethnographic research, linguistic approaches, sociocultural theory and ethnomethodological conversation analysis (Mercer, 2010; Mitchell, 2009; Rampton et al., 2002). The development of these approaches has been addressed elsewhere (e.g. Ellis, 2008, pp. 781-783; Mitchell, 2009, pp. 676-678). In the following part of this section we outline some reviews of research on classroom interaction, on which the present study is based.

As far as research on classroom interaction conducted outside the Czech Republic is concerned, there exist a number of reviews of research from various fields of education, e.g. mathematics (Walshaw \& Anthony, 2008) 
or reading comprehension (Nystrand, 2006). More specifically, in the field of foreign language teaching, there are a number of reviews (e.g. Chaudron, 1988; Ellis, 2008, pp. 775-835; Hall \& Walsh, 2002; Nunan, 1991, 2005; Thoms, 2012), in all of which theoretical and methodological plurality of research is reflected.

As far as the situation in the Czech Republic is concerned, Mareš (1990) analyzed the research on classroom interaction conducted in Czechoslovakia before 1989 and pointed out some shortcomings. In addition, Mareš (2009) reviewed the studies conducted between 1990 and 2009. There are also reviews of relevant research as parts of monographs (e.g. Janíková, 2011, pp. 36-40). In this study we also build on our previous work (Tůma, 2014), in which we reviewed research articles on classroom interaction published in four Czech educational journals between the years 1990 and 2012. In the present study we adopt the same theoretical position (dialogism) and conduct a critical analysis in the light of dialogism. It should be pointed out that in the previous study (Tüma, 2014) we found no studies on classroom interaction in foreign language classrooms, therefore there is no overlap with the present study regarding the publications reviewed. It follows that in this study we narrow down the scope of the former review by focusing solely on English language teaching and, at the same time, we extend the scope to publications of other types (books, book chapters and Ph.D. dissertations). Furthermore, studies published in 2013 and in approximately the first half of 2014 are included in the present study.

In addition, we build on our previous study (Tůma \& Píšová, 2013), in which we analysed the foci of Ph.D. dissertations defended in the field of foreign language didactics in the Czech Republic (2006-2012) and compared the results with reviews of Ph.D. dissertations from selected countries. For the purposes of the present study, relevant works were analyzed in more detail.

\section{Methodology}

The aim of this study is to present a critical review of research on classroom interaction in English language teaching conducted in the Czech Republic. We answer the following research questions: What empirical studies were conducted? What were their research questions and methodological characteristics? To what extent is dialogism reflected in the studies? 
Before presenting the methodology of this review, we briefly introduce some specific aspects related to Czech publishing platforms. It should be pointed out that there are journals which are included in international databases such as EBSCO or Scopus, however, not all of their issues have been indexed in the databases, which considerably limits the effectiveness of database search $^{6}$. On the other hand, there exists the Information Register of Research and Development Results (henceforth RIV) ${ }^{7}$, which is run by the Research, Development and Innovation Council. However, in contrast to international research databases, the search options of the register are considerably limited. Furthermore, RIV seems to be designed and used for economic rather than research purposes ${ }^{8}$ and the legislation related to including records in the register seems to undergo changes on an annual basis. For the purposes of this review, we complemented the search in RIV by a number of other specialized databases and indices, including the Educational Library of J. A. Comenius ${ }^{9}$, a database of Czech authors publishing (mainly) in the field of English philology ${ }^{10}$ and a database of Czech Ph.D. dissertations defended in the field of foreign language didactics (titles and abstracts) created for the purposes of a thematic analysis (Tủma \& Píšová, 2013) ${ }^{11}$. In addition, we cross-checked the lists of references from the above-mentioned reviews and relevant publications which we found during the search process in order to minimize the risk of not including a pertinent study. Last but not least, we scanned the issues of four Czech educational journals published since 2013 manually in order to include the most recent works and update our previous review (Tůma, 2014, p. 201).

As regards the scope of the review, we incorporated platforms for academic research, including journal articles, Ph.D. dissertations, books and book chapters. Conference proceedings were not included in this review, since they tend to present working papers (Mareš, 2013, p. 449) and since some

For example, Pedagogická orientace has been indexed in EBSCO Educational source since 2013. In Czech Rejstř́k informací o výsledcích, http://www.vyzkum.cz/FrontClanek.aspx?idsekce $=1028$

8 Jansová and Vavř́ková (2011) point out that the perception of RIV has changed; initially it was not understood as a basis for the funding of research organizations.

9 http://npmk.cz

10 http://www.mluvniceanglictiny.cz/citace

11 We updated the database by including the data from the year 2013 and the first half of 2014 . The full texts of relevant Ph.D. dissertations were retrieved from the online archives of the respective universities. 
conference proceedings are not peer-reviewed, which may influence the quality of the papers (Píšová, Janíková, \& Hanušová, 2011, p. 21).

As far as the time period is concerned, we included works published or defended from 2006 to 2013, i.e. a period of eight years. The choice of the beginning of this period was influenced by the scope of the database of Ph.D. dissertations (Tůma \& Píšová, 2013) ${ }^{12}$ and also by the fact that empirical research on classroom interaction in the four major Czech educational journals was basically divided between the periods of 1990-1994 and 2005-2012 (Tůma, 2014, pp. 183-184) ${ }^{13}$. In addition, we included studies from 2014, however, this review does not cover the year in its entirety since after the time of submitting this text for review a number of relevant studies dated 2014 may be published.

As far as keywords are concerned, the terms communication and interaction (and their Czech equivalents) ${ }^{14}$ were searched for in the titles of the publications, abstracts and/or in the keywords depending on the search possibilities of the search engines. From the total of 2,203 items obtained, the items whose titles were clearly irrelevant to classroom interaction were excluded. Next, the abstracts or annotations were processed in order to exclude the studies related to other school subjects than English. Full texts of 33 items were then retrieved and processed, which included the scanning of their bibliographies for other relevant studies.

In addition, only studies dealing with the processes of actual classroom interaction during teaching were kept in the corpus. This means that studies dealing with (rather static) characteristics of the participants (e.g. interaction styles) or contexts for interaction (e.g. classroom climate) were excluded. In some cases, the decision on inclusion or exclusion was made on the basis of the annotation, provided that the annotation included enough information. In other cases, the decision was made on the grounds of scanning the full text of the study. In the end, there were 25 studies which were analysed in more detail.

12 At some universities, older Ph.D. dissertations are not available online.

13 This absence of (empirical) studies before 2005 can be explained by the fact that two major grant projects addressing classroom research and classroom communication started in the years 2006 (LC06046) and 2009 (GA406/09/0752).

14 Although we suggested using the Czech term interakce ve třídě (Tůma, 2014, p. 176), other terms such as výuková interakce or pedagogická interakce are widely used. Therefore, for the purpose of database search, we used a more general term interakce. The same applies to the Czech translation of classroom communication. As regards the English keywords, the terms classroom talk and teacher talk were also used. 


\subsection{The analysis of the studies}

The analysis of the 25 studies was conducted in two stages. The aim of the first stage was to distinguish empirical research studies from reviews, theoretical papers and articles presenting their authors' opinions or introducing developmental projects or teaching methods. The criteria for empirical research studies were: referring to literature, providing information on the research sample, data source and method of analysis, and presenting results. On the basis of applying these criteria, 10 studies were excluded.

For the remaining 15 studies, the bibliographical data were recorded and methodological aspects were extracted, including research questions ${ }^{15}$ related to the actual classroom interaction in the processes of English language teaching. The studies were analyzed in the light of dialogism.

\section{Dialogism reflected in the studies}

As we pointed out in section 2, dialogism presents an epistemological and theoretical position for our understanding of interaction. Linell (1998, p. 9) supposes that "there can be a monologistic theory of dialogue, and a dialogistic theory of monologue". It follows that the phenomenon which we call classroom interaction can be approached from the perspective of monologism or dialogism. It should be pointed out that an explicit grounding of the studies in dialogism was not required for their inclusion in this review. However, in the analysis and subsequent discussion we employ the perspective of dialogism. We will return to this point in the discussion of findings.

The extent to which dialogism was reflected in each empirical study was investigated from three angles: (1) declared theoretical positions, (2) interaction as a unit of analysis and (3) taking context into consideration during the data analysis. We will discuss these three perspectives in more detail below when introducing the results of the analysis.

15 In some cases, research questions were not explicitly formulated. Then, the aims of the empirical research were extracted instead. 


\section{$4 \quad$ Results}

Altogether, there were 15 empirical studies (4 books, 5 journal articles, 3 book chapters and 3 Ph.D. dissertations). However, during the analysis it became clear that some studies (re)introduced the results of some previously published studies. For instance, some studies were published as book chapters and subsequently with some elaboration as journal articles, or Ph.D. dissertations were later published as books. Such redundant items were excluded so that the most current and most elaborate studies remained in the corpus. After these considerations, there were 9 studies ( 4 books, 3 journal articles, 1 book chapter and 1 Ph.D. dissertation) on which this review is based.

We present the empirical studies and their methodological characteristics chronologically in Table $1 .{ }^{16}$ It should be pointed out that only the research questions which were relevant to the analysis of the actual classroom interaction in English language teaching were extracted. ${ }^{17}$ Relatedly, the information about the data source (audio- or video-recordings) was extracted in relation to the actual classroom interaction. ${ }^{18}$ As far as the level of education is concerned, the majority of studies focused on primary or lower-secondary schools. ${ }^{19}$ There were no studies centred upon the tertiary level. The information about the sample captures the number of lessons (and the number of different teachers if available). The last column introduces the information about the geographical location of the schools in which the data were collected.

From Table 1 it follows that seven out of the nine studies were based on a large videostudy conducted by the Institute for Research in School Education (IRSE, Faculty of Education, Masaryk University, Brno). Table 1 also shows

16 Table 1, due to its landscape orientation, can be found at the end of the article.

17 In addition, in seven cases the research questions were translated into English by the author of this study, since two items were written in English, one in Slovak and six in Czech.

18 In some studies, for example, questionnaires or interviews were also used. We did not analyze these aspects of research due to the focus of this review on classroom interaction as such.

19 In the Czech Republic the educational system is divided into five years of the primary level (ISCED 1, learners aged approximately 6-10), four years of the lower-secondary level (ISCED 2, learners aged approximately 11-15) and secondary level (ISCED 3, learners older than 15). More information about the Czech system of education can be found, for example, on the website of the Ministry of Education, Youth and Sports (http://www.msmt.cz/ file/21631/download/). 
that the majority of studies are focused on compulsory school education, namely its lower-secondary level. There is only one study which focuses on secondary education (Šipošová, 2011). This study is also specific in that it is the only study which was not conducted in the Czech Republic. However, the fact that the study was defended as a Ph.D. dissertation at a Czech university as well as the historical and cultural interconnectedness between the Czech Republic and Slovakia and the similarity of the Czech and Slovak languages supported the decision to include the study in this review.

Table 1 also shows that there were a number of different research questions, according to which we can categorize the studies. One group comprises studies building on IRF exchanges (Betáková, 2010) and more specifically on teacher questions (Šipošová, 2011). One study deals with learner utterances in relation to the nature of classroom activities (Hanušová et al., 2014). Another group is represented by a study dealing with classroom language, i.e. the use of the mother tongue or the target language (Najvar, Janík, \& Šebestová, 2013). Furthermore, there are two studies which mainly deal with communication and relatedly (intercultural) communicative competence as the goal of foreign language teaching (Šebestová, 2011; Zerzová, 2012), whose results were synthetized in Zerzová and Šebestová (2014). One study deals with gender issues (Doskočilová, 2012). Another study is related to more general educational issues, such as interaction patterns, lesson phases or the use of teaching aids, and introducing these along with domain-specific aspects of language teaching, such as classroom language (Najvar, Najvarová, Janík, \& Šebestová, 2011). Although Najvar et al. (2011) (re)introduce (some of) the results of other studies (Hanušová et al., 2014; Najvar et al., 2013; Šebestová, 2011; Zerzová, 2012), we decided not to exclude any of the studies, since each of them declares different theoretical background, which was one of the aspects that were analyzed in the light of dialogism.

\subsection{The empirical studies from the perspective of dialogism}

We analyzed the studies in the light of dialogism from three perspectives: (1) declared theoretical positions, (2) interaction as a unit of analysis and (3) taking context into consideration during the data analysis. We should point out that in dialogism these three perspectives are interconnected, yet for analytical purposes we analyze them one by one. We prefer discussing the findings in the form of text to presenting the results in a table, since the 
textual form of presenting results makes it possible to refer to the mutual links among the aspects of the analysis. While adopting the perspective of dialogism, we also inevitably refer to monologism, which presents a countertheory to dialogism.

\section{Theoretical positions}

As far as theoretical positions of the studies are concerned, we extracted the declared theoretical background for each study. From the studies focusing on classroom interaction from a more linguistic perspective, Betáková (2010, pp. 11-149) introduces a wide range of concepts and approaches including selected aspects of discourse analysis, classroom discourse and teacher talk, and methodologies for analyzing classroom processes, from which she adopts mainly interactional analysis and related concepts of IRF in her analysis. IRF is also adopted by Šipošová (2011), who focuses solely on teacher questions and introduces related taxonomies. More generally, the IRF exchange has its roots in constitutive ethnography (Mehan, 1979) and in linguistic approaches to classroom interaction (Sinclair \& Coulthard, 1975). In both of these ways of approaching IRF, the individual moves are linked to higher-level units and, at the same time, to each other and lowerlevel acts, which is compatible with dialogism as the actual interaction rather than the activity of an individual is analyzed. As Bakhtin (1986, p. 91) puts it, "any concrete utterance is a link in the chain of speech communication" and "utterances are not indifferent to one another, and are not self-sufficient; they are aware of and mutually reflect one another." From the two empirical studies in this review, Betáková (2010) in her analysis seems to approach IRF in a way compatible with dialogism, while for Šipošová (2011) IRF seems to represent an instrument for segmenting the recorded material, making it possible to focus on teacher questions, i.e. on the activity of the teacher, thus being grounded in monologism.

Apart from IRF, the specifics of foreign language teaching and classroom interaction are discussed in a number of studies (the most elaborate accounts can be found in Betáková, 2010; Šipošová, 2011). Next, the issues related to the use of the mother tongue and English in English language teaching are introduced in several studies (Hanušová et al., 2014; Šebestová, 2011) and, more specifically, these issues are referred to as code-switching (Najvar et al., 2013). As far as the specifics of foreign language teaching are concerned, two studies declare the four skills and/or the concept of communicative competence as their theoretical background (Šebestová, 2011; Zerzová \& Šebestová, 
2014). By the same token, Šipošová (2011) introduces the speaking skill as a part of the Slovak school leaving examination and, in addition, discusses communicative language teaching, which is also taken as a theoretical position by Hanušová et al. (2014). Culture-related issues are also taken into consideration along with intercultural communicative competence (Zerzová, 2012; Zerzová \& Šebestová, 2014). All of the positions mentioned in this paragraph seem to reflect the dual function of language in foreign language teaching, yet the related SLA accounts seem to refer to monologist theories, namely Long's Interaction Hypothesis (Šebestová, 2011, p. 40) or Krashen's Comprehensible Input Hypothesis (Betáková, 2010, p. 57; Hanušová et al., 2014, p. 239; Šebestová, 2011, p. 39). SLA theories compatible with dialogism, e.g. SCT (Lantolf \& Thorne, 2006), are not referred to in any of the studies.

Other theoretical perspectives include gender (Doskočilová, 2012) and the quality of teaching (Najvar et al., 2011). One of the most prevalent theoretical positions is the concept of opportunities to learn (Najvar et al., 2011; Šebestová, 2011; Zerzová, 2012; Zerzová \& Šebestová, 2014), which appears to imply an analysis of time allocated to different classroom activities during which the learners are expected to learn (e.g. Najvar et al., 2011, p. 91). As Knecht (2014, p. 165) puts it, the concept of opportunities to learn seems to result in creating elaborated systems of categories and scales which subsequently serve for description, and he adds that "the results of these studies are rarely related to theoretical background of the research ... [, which] raises the question whether opportunities to learn represent a useful theoretical construct". Furthermore, an analysis of time allocated to different activities seems to imply an atomist approach and thus theoretically making it impossible for two activities to overlap. This view is clearly a monologist one. Interestingly, two of the newest studies building on the IRSE videostudy data do not declare their theoretical grounding in opportunities to learn any more (Hanušová et al., 2014; Najvar et al., 2013).

\section{Interaction as a unit of analysis}

As we suggested above, theoretical positions seem to imply the way the recorded material is analyzed. This was another step in our critical analysis. Out of the total of nine studies, seven studies used 10 -second intervals as units of analysis, which were subsequently analyzed in the light of one or more systems of categories (Doskočilová, 2012; Hanušová et al., 2014; Najvar et al., 2011, 2013; Šebestová, 2011; Zerzová, 2012; Zerzová \& Šebestová, 2014). Two of these studies (Najvar et al., 2011, 2013) also used individual words 
(which were counted) as units of analysis and in one study (Doskočilová, 2012) the occurrence of certain phenomena was counted in the videorecordings irrespective of the time intervals. Šipošová (2011) analyzed questions asked by teachers in the light of a category system, regardless of learner responses, thus taking teacher questions as units of analysis. All of these units of analysis (10-second intervals, an occurrence of a phenomenon regardless of the previous/subsequent phenomena) seem to be grounded in monologism, since in dialogism the actual contextualized utterances and their mutual connectedness would be analyzed (e.g. Linell, 2009, pp. 11-33).

In one study (Betáková, 2010), the material is approached in a complex way in which links among individual utterances were sought, thus being more compatible with dialogism. However, one part of the analysis deals with individual segments (mainly the initiation and follow-up turns produced by the teacher) in the light of systems of categories, thus adopting an etic rather than an emic perspective. In this respect the analysis lies in a monologist quantification of the phenomena rather than a dialogist description of the mechanisms underlying interaction.

Najvar et al. (2013, pp. 838-840) present five types of situations in which they observed code switching, which would seem compatible with dialogism. However, they do not introduce a rationale for selecting the situations. They add that the situations should be taken as examples of "how languages can be mixed ... rather than a result of a systematic analysis" (Najvar et al., 2013 , p. 838). Therefore it does not seem that a methodological reflection of dialogism can be observed in the analysis.

\section{The role of context in the analysis}

In this part of our analysis, we paid attention to the way context was dealt with in the individual empirical studies, particularly whether contextual factors such as the topic or content of interaction, characteristics of the participants, the settings or the content of neighbouring utterances were taken into consideration during the analyses.

In a number of cases it was difficult to assess the role of context since the majority of analyses, as pointed out above, seemed to be firmly grounded in monologism, which implies that utterances can be separated from their contexts and subsequently analyzed in (relative) isolation (Linell, 1998, pp. 36-37; Vološinov, 1973, p. 72). It follows that context was not paid much attention to in the description of the analytic procedures. The analyses seem 
to range from those approaching their units of analysis in total isolation (Šipošová, 2011) to studies whose detailed coding manuals and category systems implied taking some contextual data into consideration. For example, in her coding manual, Šebestová (2011, pp. 145-158) notes that the actual classroom activity should be coded as a whole and that overlaps of two activities within the 10-second intervals are allowed. Similarly, from the coding manual prepared by Zerzová (2012, pp. 179-200) it follows that some contextual data (e.g. lesson phases) were inferred from larger units than the actual 10-second intervals. In one study, the learners' sex was taken into consideration (Doskočilová, 2012). These findings seem to suggest that although context was somehow dealt with in some of the analyses, the dynamic nature of context (i.e. its re-constructing during the actual interaction) was not appreciated, which seems to support the underlying monologist assumption that "unique or dynamic contexts are not essential [...] for the understanding of the specific thoughts, situated behaviors, utterances or texts, let alone of the underlying language system" (Linell, 2009 , p. 36). On the other hand, in one analysis attention was paid to the neighbouring utterances and (where appropriate) to intonation (Betáková, 2010), which seems to suggest a more dialogist position.

Although some studies attempted to capture different types of classroom activities (Hanušová et al., 2014; Najvar et al., 2011, pp. 145-149) or the use of teaching aids and media (Najvar et al., 2011, pp. 119-120; Zerzová, 2012, pp. 105-109), the studies do not reveal the nature of the actual interaction in these activities or when using different teaching aids or media. It is therefore impossible to analyze the way they deal with context (e.g. the use of teaching aids) in the analyses. We discuss this in the following section.

\section{$5 \quad$ Discussion of findings}

In this section we discuss the above results first in relation to the phenomenon of classroom interaction and second in relation to the results of other reviews of research on classroom interaction (both Czech and international).

Table 1 indicates that there was a wide range of research questions in the studies. In some studies, the scope seemed to be more general than classroom interaction (e.g. Najvar et al., 2011; Šebestová, 2011), thus falling into the realm of research on teaching and learning. On the other hand, the studies in question seem to address some issues that clearly fall into the realm of 
classroom interaction, such as the use of the mother tongue and the target language. ${ }^{20}$ This was the reason for including these studies in the review.

From the research questions and theoretical positions it seems that a lot of attention is paid to the field of teacher talk, namely teacher questions. Indeed, similar findings can be found in other reviews (Chaudron, 1988, pp. 126-132; Ellis, 2008, pp. 797-801; Nunan, 1991, 2005, p. 228), yet some research reviewed in international studies also takes the elicited learner output into consideration. Furthermore, both of the Czech studies addressing teacher questions (Betáková, 2010; Šipošová, 2011) are etic. This type of research is criticized by McCormick and Donato (2000, as cited by Ellis, 2008, p. 801), for "simply assigning questions to some pre-determined functional category is misleading" and "questions need to beviewed as dynamic discursive tools that serve to build collaboration and to scaffold comprehension and comprehensibility". This clearly illustrates the tension between monologist and dialogist views on questions and answers (and interaction in general).

As far as other aspects of teacher talk are concerned, turn-taking was addressed in one study (Betáková, 2010; for studies conducted abroad, see Ellis, 2008, pp. 790-792) and it seems that the field of error correction has not been addressed in any of the Czech studies, whereas international research pays considerable attention to the phenomena of error treatment and feedback (for reviews, see Chaudron, 1988, pp. 132-152; Ellis, 2008, pp. 803-806; Mitchell, 2009, pp. 681-682; Nunan, 2005, pp. 228-229).

As far as the use of the target language and mother tongue is concerned, it should be pointed out that different SLA theories seem to present different (if not contradictory) views on the role and value of the mother tongue in foreign language teaching. ${ }^{21}$ Not surprisingly, the studies both in the Czech Republic and abroad attempt to address the ratio of the mother tongue (L1) to the target language (L2). However, as Chaudron (1988, p. 124) puts it, "the total proportion of L1 or L2 use alone is probably not the critical variable in determining the degree of L1 maintenance or L2 acquisition" and "it is

20 The borderline position of some studies seems to be evident from the information that the authors themselves provided about the publications. For example, the RIV record of Šebestová (2011) includes keywords such as "mother tongue", "target language" and "teaching and learning", but neither does the book nor the RIV record include "classroom interaction".

21 For example, in the light of Krashen's Comprehensible Input Hypothesis, learners should benefit from the comprehensible input in the target language, whereas in Sociocultural Theory the mother tongue can be seen as helpful in the learning process. 
the functional allocation of the TL [target language] relative to the L1 ... which would indicate to the learner the priorities of the extended social environment that schools and teachers represent." Although the Czech studies (Betáková, 2010, pp. 197-198; Najvar et al., 2013, 2011, pp. 143-145) reported considerable variation among individual teachers ${ }^{22}$, they do not seem to provide answers to the question why the ratio was so varied or how it was functionally distributed (this issue has only been partially addressed by Betáková, 2010; see also Chaudron, 1988, pp. 52-54, 124-125).

The communicative nature of activities is dealt with in Czech research (Hanušová et al., 2014; Najvar et al., 2011, pp. 147-149) as well as international research (Ellis, 2008, pp. 784-786; Nunan, 2005, pp. 232-233). The latter, however, seems to reflect the nature of communicative activities (e.g. information gap, incorporation of preceding utterances, the degree of control over linguistic form) more in-depth and in a way that seems more compatible with dialogism.

As we pointed out in section 4.1, there are studies in which IRF appears to be used as an instrument for segmentation rather than for the characterization of the nature of exchanges (see Ellis, 2008, pp. 786-788; Hall \& Walsh, 2002; Thoms, 2012, pp. 511-513; for reviews of more dialogist treatment of IRF). This monologist treatment was observed in a more general review of Czech educational research on classroom interaction (Tůma, 2014, pp. 187188). It seems that some authors tend to treat the IRF exchange structure in a neobehaviorist (and thus monologist) way as stimulus-reactionreinforcement (see also Linell, 2009, p. 22).

As far as research on classrooms as social communities is concerned, there seems to be a gap in Czech research (for a review of international research, see Mitchell, 2009, pp. 690-693). None of the Czech studies in this review adopted an ethnographic design or addressed social issues in classroom interaction. One exception is Doskočilová (2012), who investigated gender inequalities, yet she adopted a monologist rather than a dialogist orientation (see section 4.1). This monologist way of dealing with gender has been observed in other Czech studies (Tưma, 2014, p. 188). It seems that Czech educational research on classroom interaction does not take the social construction of gender into account in the actual analyses. ${ }^{23}$

22 Ellis (2008, p. 802) also refers to considerable variation within individual teachers.

23 On the other hand, sociological research seems to address gender in a more dialogist way (see, for example, Jarkovská, 2009). 
Learners' contribution to classroom interaction presents another area which seems to be relatively underresearched. On the one hand, learner participation is addressed in some studies (e.g. from the perspective of gender in Doskočilová, 2012). On the other hand, the areas of learner initiative, learner questions or learner-learner interaction do not seem to be examined by Czech researchers, at least from the field of foreign language teaching (for reviews of international research in these areas, see Chaudron, 1988, pp. 90-109; Ellis, 2008, pp. 807-833; Thoms, 2012, pp. 518-520).

Finally, we can compare the findings to the outcomes of an analysis capturing Czech educational research on classroom interaction more generally. Similarly to studies from the 1990s (as reviewed in Tủma, 2014, p. 183), the studies in the present review tend to deal with utterances in isolation and attempt to quantify certain phenomena, which was, among other things, criticized by Mareš (1990, p. 97) as a drawback of Czechoslovak educational research on classroom interaction conducted before 1989.

As regards the levels of education, the studies in Table 1 address mainly lower-secondary schools, yet the coverage of primary schools seems to be better than in the studies reviewed in Tüma (2014, pp. 183-184). Classroom interaction in tertiary education does not appear to be addressed and secondary education level is also covered rather marginally (see also Tůma, 2014, pp. 183-184).

Methodologically, video-recordingseems to bea prevalentmethodincapturing classroom interaction. While the samples in the present review ranged between 3 and 89 lessons, the studies reviewed in Tủma (2014,pp. 183-184) analyzed between 8 and 60 lessons. $^{24}$

\section{Conclusion}

In the above discussion we addressed some of the gaps which Czech research on classroom interaction in English language teaching may fill in the future. In this place we will address a more general issue related to the paradigmatic orientation of the studies reviewed.

The studies in Table 1 have outlined some of the quantitative parameters of Czech EFL classroom interaction, such as the numbers of words uttered

24 Some studies, however, employed direct observation and it was not clear in some studies from the early 1990s whether the lessons were observed directly or indirectly. 
by the persons involved, the proportion of Czech and English, the ratios of different types of questions uttered by teachers or the allocation of time in which the learners have the opportunity to develop (intercultural) communicative competence. These proportions have been counted in line with the monologist research tradition and can be seen as useful overall characteristics of EFL classrooms in the Czech Republic. However, the research so far seems to reveal little about the nature of classroom interaction - for example, we do not know when and for what purposes the teachers used the mother tongue, what kinds of responses teacher questions elicited or how the activities related to developing (intercultural) communicative competence were conducted. In this respect we can refer to Fodor, a representative of the monologist tradition, who holds that "what our cognitive science has done so far is mostly to throw some light on how much dark there is" (Fodor 2000, as cited in 0'Connell \& Kowal, 2003, p. 206). In order to address research questions related to the nature of classroom interaction, it seems that a different paradigmatic orientation should be adopted. In this respect, we suggest that dialogism can serve as a theoretical and epistemological platform.

As we pointed out in section 1, from the nature of foreign language teaching it follows that language plays a dual role in the process of teaching and learning: it serves both as a medium (i.e. a tool) and as a goal in foreign language teaching. In this respect, the background provided by monologism seems inadequate, as from a monologist perspective, tools and goals present distinct categories. This seems to explain the fact that none of the studies in this review addressed classroom interaction empirically in relation to learning. In contrast, dialogism seems to have the potential to cast light on the interconnectedness of tools and goals. The presupposed intersubjectivity in interaction, the reflexive relationship between tools and goals or language and context seem to be in line with the social view on SLA proposed by, for example, Firth and Wagner (2007). Furthermore, it has been suggested that there exists a reflexive relationship between pedagogy and interaction (Seedhouse, 2004).

Monologism, in whose tradition a majority of the reviewed studies have been conducted, does not seem to provide the views which would address the interdependence among interaction, pedagogy and learning. Therefore one may ask the question why more dialogist research is not conducted. It is beyond the scope of this review to discuss this question in detail but two 
answers can be outlined. First, it has been criticized that monologism has been a dominant paradigm in psycholinguistics (e.g. O'Connell \& Kowal, 2003) and social psychology (e.g. Marková, 2007, p. 11). Relatedly, the historical roots of the disciplines in monologism (as well as the relation to natural sciences) are often referred to. From this perspective, we are in fact addressing the essence of social sciences and how they relate to natural sciences (e.g. Linell, 2009, pp. 28-31; Marková, 2007, p. 120). Second, we can emphasize the fact that the issue of the focus on the individual or interaction seems to be recurrent not only in social psychology or psycholinguistics, but also in education (see, for example, Slavík, 1995). It may follow that the static nature of context (if considered in the actual analysis at all) or the transmissive model of communication (as presupposed in monologism) may appear relatively simpler than the dynamic view of context and interdependencies among interaction, learning, thinking and pedagogy (as assumed in dialogism). Relatedly, we can refer to the view that "the language of dialogue is disorderly compared to the straightforward grammatical sentences of monologue", and conclude that "as one grants this assumption of chaos, one must simply give up on dialogue" (Garrod \& Pickering, 1999, as cited in O'Connell \& Kowal, 2003 , p. 200). This illustrates that the understanding of interaction in its complexity, situatedness and dynamics requires a relatively complex (and completely different) framework, which may seem "disorderly" or "chaotic" for those working in the monologist tradition.

As Marková (1982, p. 3) puts it, "it should be possible to change from one framework to another but this is not usually easy and may even prove to be psychologically impossible". However, she adds that if we are not aware of the paradigm in which we work and of the presuppositions that the paradigm implies, "we are unable to reflect upon them and consequently to consider alternatives to the adopted ways of thinking and researching" (Marková, 1982, p. 3). We can assume that Czech educational research on classroom interaction, both in general and in the field of English language teaching specifically, would benefit from the possibilities which dialogism affords, both theoretically and methodologically.

\section{References}

Bakhtin, M. M. (1986). Speech genres and other late essays. (V. W. McGee, Trans., C. Emerson \& M. Holquist, Eds.). Austin: University of Texas Press.

*Betáková, L. (2010). Discourse and interaction in English language teaching. Praha: Pedagogická fakulta Univerzity Karlovy. 
Chaudron, C. (1988). Second language classrooms: Research on teaching and learning. Cambridge University Press.

Cook, V. (2010). Prolegomena to second language learning. In P. Seedhouse, S. Walsh, \& C. Jenks (Eds.), Conceptualising 'learning' in applied linguistics (pp. 6-22). London: Palgrave Macmillan.

*Doskočilová, M. (2012). Genderové nerovnosti ve výuce angličtiny: kategoriální systémy a první kvantitativní sonda. In T. Janík \& K. Pešková (Eds.), Školní vzdělávání: podmínky, kurikulum, aktérí, procesy, výsledky (pp. 217-229). Brno: Masarykova univerzita.

Ellis, R. (2008). The study of second language acquisition. Oxford: Oxford University Press.

Firth, A., \& Wagner, J. (2007). Second/foreign language learning as a social accomplishment: Elaborations on a reconceptualized SLA. The Modern Language Journal, 91, 800-819.

Hall, J. K., \& Walsh, M. (2002). Teacher-student interaction and language learning. Annual Review of Applied Linguistics, 22, 186-203.

*Hanušová, S., Najvar, P., Adam, M., Najvarová, V., \& Homolka, S. (2014). Povaha žákovských promluv ve výuce anglického jazyka. Pedagogika, 64(2), 236-253.

Janíková, M. (2011). Interakce a komunikace učitelů tělesné výchovy. Brno: Paido.

Jansová, L., \& Vavř́íková, L. (2011). Zpráva ze semináře Organizace sběru dat do RIV. Informace, 20(1-2). Retrieved from http://www.lib.cas.cz/casopis-informace/zprava-ze-seminareorganizace-sberu-dat-do-riv/

Jarkovská, L. (2009). Školní třída pod genderovou lupou. Sociologický časopis / Czech Sociological Review, 45(4), 727-752.

Knecht, P. (2014). Př́ležitosti k učení: odlišná/různá pojetí konceptu a jeho výzkumné využití. Pedagogická orientace, 24(2), 163-184.

Lantolf, J. P., \& Thorne, S. L. (2006). Sociocultural theory and the genesis of second language development. Oxford: Oxford University Press.

Larsen-Freeman, D., \& Freeman, D. (2008). Language moves: The place of 'foreign' languages in classroom teaching and learning. Review of Research in Education, 32(1), 147-186.

Linell, P. (1998). Approaching dialogue. Talk, interaction and contexts in dialogical perspectives. Amsterdam: John Benjamins Publishing Company.

Linell, P. (2009). Rethinking language, mind and world dialogically. Interactional and contextual theories of human sense-making. Charlotte: Information Age Publishing.

Luckmann, T. (1990). Social communication, dialogue and conversation. In I. Marková \& K. Foppa (Eds.), The dynamics of dialogue (pp. 45-61). New York: Harvester Wheatsheaf.

Mareš, J. (1990). Zamyšlení nad čs. výzkumy pedagogické interakce a komunikace. In Súčasný stav a perspektívy pedagogického výskumu (pp. 85-104). Bratislava: Ústav experimentálnej pedagogiky SAV.

Mareš, J. (2009). Posledních dvacet let výzkumu pedagogické interakce a komunikace v České republice (léta 1990-2009). In Pedagogická komunikace $v$ didaktických, sociálních a filozofických souvislostech. Sborník př́spěvků z konference (pp. 9-29). Hradec Králové: Gaudeamus.

Mareš, J. (2013). Přehledové studie: jejich typologie, funkce a způsob vytváření. Pedagogická orientace, 23(4), 427-454.

Marková, I. (1982). Paradimgs, thought, and language. Chichester: John Wiley \& Sons.

Marková, I. (2007). Dialogičnost a sociální reprezentace: Dynamika mysli. (H. Šolcová, Trans.). Praha: Academia. 
Mehan, H. (1979). Learning lessons. Cambridge: Harvard University Press.

Mercer, N. (2010). The analysis of classroom talk: Methods and methodologies. British Journal of Educational Psychology, 80(1), 1-14.

Mitchell, R. F. (2009). Current trends in classroom research. In M. H. Long \& C. J. Doughty (Eds.), The handbook of language teaching (pp. 675-705). Chichester: Blackwell Publishing Ltd.

*Najvar, P., Janík, T., \& Šebestová, S. (2013). The language of communication in English classrooms in the Czech Republic: Mixing languages. Pedagogická orientace, 23(6), 823-843.

*Najvar, P., Najvarová, V., Janík, T., \& Šebestová, S. (2011). Videostudie v pedagogickém výzkumu. Brno: Paido.

Nunan, D. (1991). Methods in second language classroom-oriented research. A critical review. Studies in Second Language Acquisition, 13(02), 249-274.

Nunan, D. (2005). Classroom research. In E. Hinkel (Ed.), Handbook of research in second language teaching and learning (pp. 225-240). New Jersey: Lawrence Erlbaum Associates.

Nystrand, M. (2006). Research on the role of classroom discourse as it affects reading comprehension. Research in the Teaching of English, 40(4), 392-412.

O'Connell, D. C., \& Kowal, S. (2003). Psycholinguistics: A half century of monologism. The American Journal of Psychology, 116(2), 191-212.

Píšová, M., Janíková, V., \& Hanušová, S. (2011). K metodologii výzkumu v didaktice cizích jazyků. In Metodologické otázky výzkumu výuky cizích jazyků. Brno: Masarykova univerzita.

Rampton, B., Roberts, C., Leung, C., \& Harris, R. (2002). Methodology in the analysis of classroom discourse. Applied Linguistics, 23(3), 373-392.

Rommetveit, R. (1988). On human beings, computers, and representational-computational versus hermeneutic-dialogical approaches to human cognition and communication. In H. Sinding-Larsen (Ed.), Artificial intelligence and language. Old questions in a new key (pp. 47-76). Oslo: Tano.

Schiffrin, D. (1994). Approaches to discourse. Malden: Blackwell Publishers.

*Šebestová, S. (2011). Příležitosti k rozvíjení řečových dovedností ve výuce anglického jazyka: videostudie. Brno: Masarykova univerzita.

Seedhouse, P. (2004). The interactional architecture of the language classroom: A conversation analysis perspective. Malden: Blackwell Publishing.

Sinclair, J. M., \& Coulthard, R. M. (1975). Towards an analysis of discourse. The English used by teachers and pupils. London: Oxford University Press.

*Šipošová, M. (2011). Otázky učitela a reakcie žiakov vo vyučovaní anglického jazyka (Ph.D. dissertation). Brno: Filozofická fakulta Masarykovy univerzity.

Slavík, J. (1995). Pojem koncept v autonomním pojetí výchovy. Pedagogika, 45(4), 328-338.

Thoms, J. J. (2012). Classroom discourse in foreign language classrooms: A review of the literature. Foreign Language Annals, 45(s1), 8-27.

Tůma, F. (2014). Dialogismus a výzkum interakce ve tř́dě: Přehledová studie (1990-2012). Pedagogika, 64(2), 175-197.

Tůma, F., \& Píšová, M. (2013). Trends in foreign language didactics research: A thematic analysis of Ph.D. dissertations from the Czech Republic and abroad (2006-2012). The New Educational Review, 34(4), 125-138.

Vološinov, V. N. (1973). Marxism and the philosophy of language. (L. Matejka \& I. R. Titunik, Trans.). New York: Seminar Press. 
Vygotsky, L. S. (1978). Mind in society: The development of higher psychological processes. (M. Cole, V. John-Steiner, S. Scribner, \& E. Souberman, Eds.). Cambridge: Harvard University Press.

Vygotsky, L. S. (1981). The genesis of higher mental functions. In J. V. Wertsch (Ed.), The concept of activity in Soviet psychology (pp. 144-188). New York: M. E. Sharpe.

Walshaw, M., \& Anthony, G. (2008). The teacher's role in classroom discourse: A review of recent research into mathematics classrooms. Review of Educational Research, 78(3), 516-551.

Wertsch, J. V. (1991). Voices of the mind. A sociocultural approach to mediated action. Herfordshire: Harvester Wheatsheaf.

*Zerzová, J. (2012). Interkulturní komunikační kompetence a její rozvíjení v hodinách anglického jazyka na 2. stupni ZŠ. Brno: Masarykova univerzita.

*Zerzová, J., \& Šebestová, S. (2014). Př́ležitosti k rozvíjení interkulturní komunikační kompetence $\mathrm{v}$ kontextu řečových dovedností: IVŠV videostudie anglického jazyka. Pedagogická orientace, 24(3), 394-422.

\title{
Author
}

Mgr. František Tůma, Ph.D., Masaryk University, Faculty of Education, Institute for Research in School Education, Poříćí 31, 60300 Brno, e-mail: tuma@ped.muni.cz

\section{Dialogismus a interakce ve výuce anglického jazyka: Přehled českého výzkumu}

\begin{abstract}
Abstrakt: Cílem předkládané studie je podat přehled o českém výzkumu interakce ve výuce angličtiny. Interakci chápeme jako vzájemné ovlivňování mezi učitelem a žáky během výuky. Na interakci ve tř́íde nahlížíme pohledem dialogismu, který chápeme jako teoretický a epistemologický rámec předpokládající interakci jako jednotku analýzy. V přehledové studii analyzujeme 9 empirických studií uveřejněných v letech 2006-2014 jako články v časopise, knihy, kapitoly v knize nebo disertační práce. Tyto studie byly kriticky analyzovány $\mathrm{z}$ pohledu dialogismu. Významným zjištěním je například skutečnost, že řada studií se zabývala jazykem učitele (teacher talk), především otázkami učitele a používáním cílového a mateřského jazyka. Tyto a další oblasti výzkumu porovnáváme s odrazem zahraniční situace ve vybraných přehledech výzkumu a poukazujeme na mezery v tuzemském výzkumu. Co se týče metodologie výzkumu (a s ní souvisejících teoretických východisek), řada studií při analýze interakce ve třídě abstrahovala od kontextu. Činnost jednotlivců (učitele, žáků) tvořila v řadě studií analytickou jednotku spíše než samotná interakce. Tato zjištění naznačují, že v empirickém výzkumu nebyl dialogismus př́liš uplatněn.
\end{abstract}

Klíčová slova: interakce ve tř́ídě, dialogismus, výuka anglického jazyka, přehledová studie 


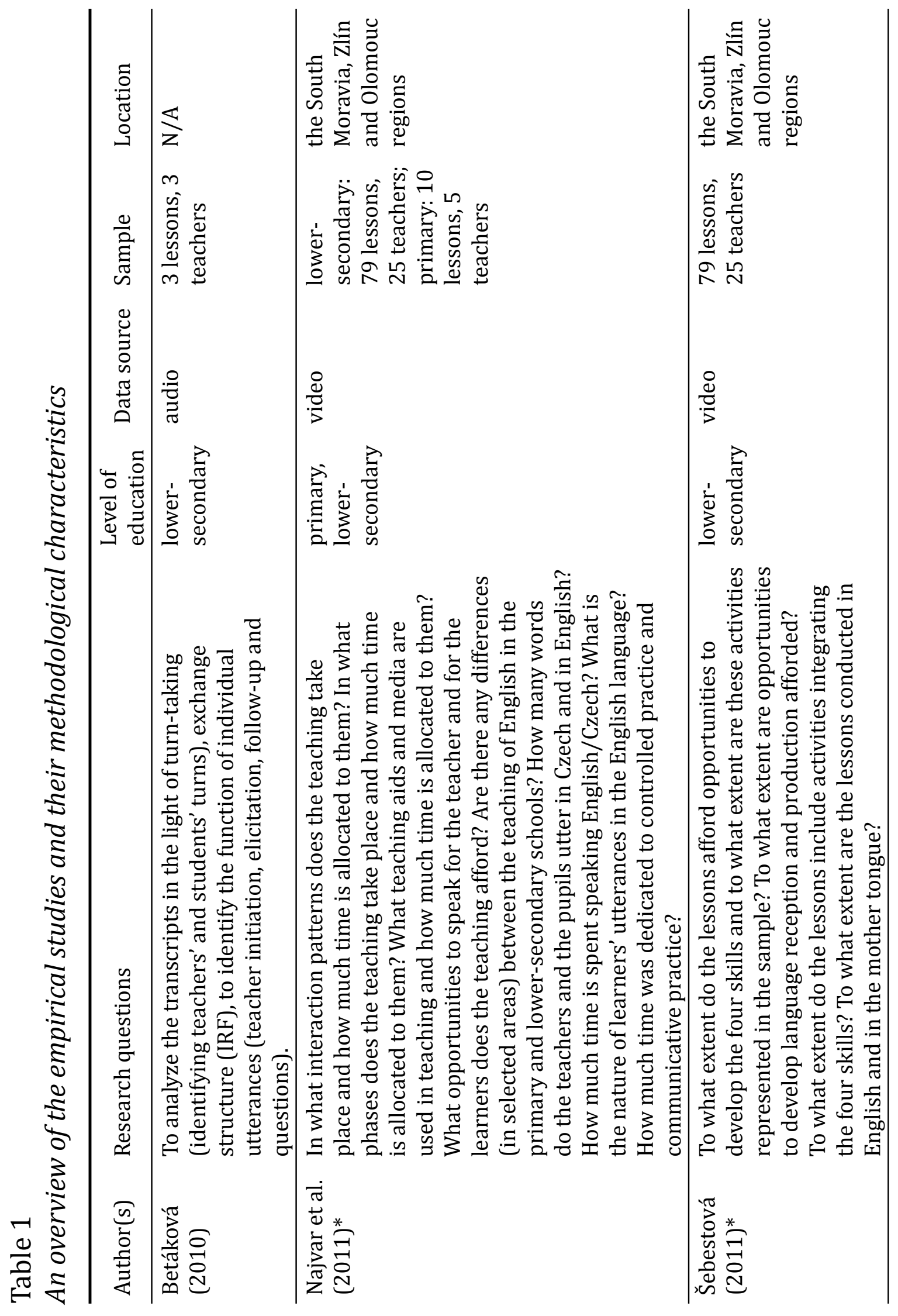




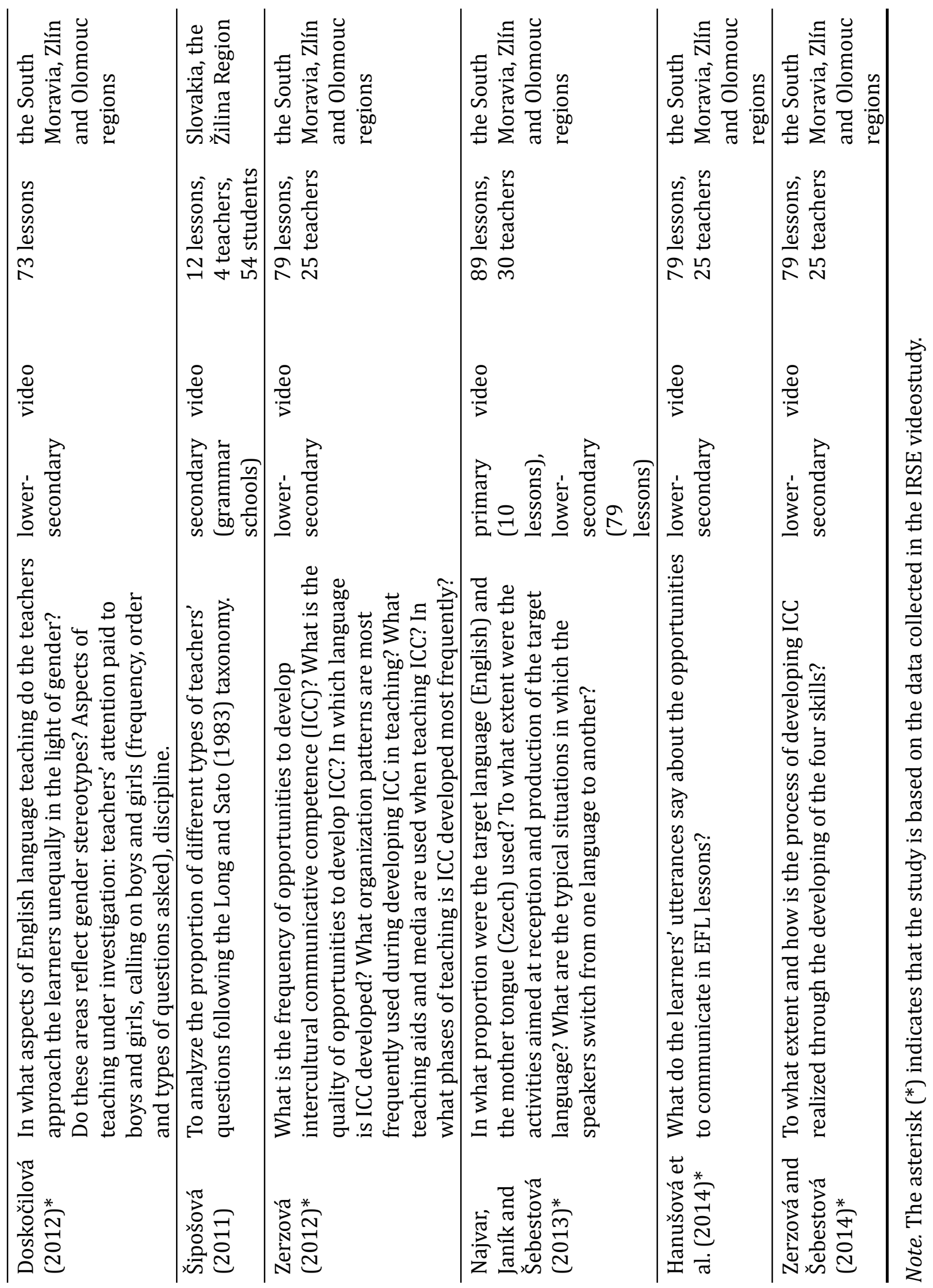

